\title{
ANALISIS OPERATIONAL EFFICIENCY DAN COST EFFICIENCY RATIO TERHADAP NET PROFIT MARGIN
}

\author{
Muliyadi Jaya \\ Email : muliyadi jaya@gmail.com
}

STIE Palangka Raya

\section{ABSTRACT}

This research aims to examine the influence of operational efficiency ratio (OER) and cost efficiency ratio (CER) toward net profit margin (NPM) at Bank Rakyat Indonesia The background of this research done is due to the bank's low rate in obtaining NPM.

Based on the classical assumption test's result, the two independent variables chosen in this research are normally distributed with no disorder found. According to the correlation test's result, it is found that OER correlates to the NPM as high as $95.6 \%$ while the CER correlates to the NPM as high as $92.7 \%$. In addition, based on the R-square test's result, it is found that both independent variables are responsible as high as $91.6 \%$ for each change in the NPM.

Based on the $\mathrm{F}$ test, it is found that both independent variables, including OER \& CER have significant influence toward NPM simultaneously, in which the P-value less than 0.05 (5\%).

The $\mathrm{T}$ test's result, however, shows that OER has negative and effect toward NPM partially, while the CER has the positive effect and the two variables have no significant effect partially. Therefore, the stepwise test is required to be done in order to get which variable that is significant partially. And this results that OER has significant and negative effect toward NPM partially with P-value less than $0.05(5 \%)$ and $t$-calculated value $[-8.030]>t-$ table [1.860]

Keyword : BOPO, CER, NPM

\section{PENDAHULUAN}

Sektor perbankan memang merupakan sector yang paling cepat terpukul jika keadaan ekonomi tidak stabil. Industri perbankan merupakan industry yang sarat dengan resiko, terutama Karena melibatkan uang masyarakat dan diputar dalam berbagai bentuk investasi, seperti pemberian kredit, pembelian surat-surat berharga dan penanaman dana lainnya. 
Perkembangan perolehan laba pada sektor perbankan beberapa tahun ini tak lepas dari membaiknya fungsi intermediasi perbankan nasional dan meningkatnya efisiensi pada biaya-biaya yang dikeluarkan oleh bank itu sendiri. Dengan kata lain, bank yang dapat menekan biaya dan mengoptimalkan kinerja operasionalnya akan mampu mendapatkan perolehan laba yang besar.

Tujuan dari penelitian ini adalah (a) Untuk mengetahui pengaruh operational efficiency ratio dan cost efficiency ratio terhadap netprofit margin pada Bank Rakyat Indonesia (BRI) secara simultan. (b)Untuk mengetahui pengaruh operational efficiency ratio dan cost efficiency ratio terhadap netprofit margin pada Bank Rakyat Indonesia (BRI)secara parsial.

\section{TINJAUAN PUSTAKA}

\section{Laporan Keuangan Bank}

Laporan keuangan bank melaporkan kinerja keuangan masa lalu dan menunjukkan posisi keuangan terakhir. Pengguna laporan keuangan bank membutuhkan informasi yang dapat dipahami, relevan, handal dan dapat dibandingkan dalam mengevaluasi posisi keuangan dan kinerja bank serta berguna dalam pengambilan keputusan ekonomi (IAI,2004). Salah satu informasi yang diperlukan investor adalah kinerja bank dalam menghasilkan laba.

Dari laporan keuangan bank dapat diketahui rasio-rasio keuangan perbankan. Dan dengan menggunakan rasio keuangan, investor dapat mengetahui kinerja suatu bank. Hal ini sesuai dengan pernyataan Muljono (1999) bahwa perbandingan dalam bentuk rasio menghasilkan angka yang lebih obyektif, karena pengukuran kinerja tersebut lebih dapat dibandingkan dengan bank-bank yang lain ataupun dengan periode sebelumnya.

Sebagai lembaga intermediasi antara pihak-pihak yang memiliki 
kelebihan dana dengan pihak-pihak yang memerlukan dana, diperlukan bank dengan kinerja keuangan yang sehat sehingga fungsi intermediasi dapat berjalan lacar. Hal tersebut tampak dalam kegiatan pokok bank yang menerima simpanan dari masyarakat dalam bentuk tabungan, giro, deposito berjangka dan memberikan kredit kepada pihak yang memerlukan dana (IAI,2004).

Laporan keuangan bank umumnya dipublikasikan dalam berbagai bentuk sesuai dengan waktu terbitnya, laporan keuangan bank berisi empat laporan utama (a) Neraca (Balance sheet) (b) Laporan laba-rugi (Income statement) (c) Laporan perubahan Ekuitas (Change of equity statement) (d) Laporan arus kas(Cash flow statement). Penelitian ini berfokus terhadap efisiensi biaya operasional terhadap perolehan net profit margin, maka jenis laporan keuangan yang digunakan dalam penelitian ini adalah laporan laba rugi atau income statement.

\section{Rentabilitas/Profitabilitas}

Rentabilitas suatu perusahaan menunjukkan perbandingan antara laba dengan modal atau biaya yang digunakan untuk menghasilkan laba tersebut. Dengan kata lain, rentabilitas merupakan kemampuan suatu perusahaan untuk menghasilkan laba selama periode tertentu (Riyanto,2001).

Menurut Silvina(2009) rentabilitas mempunyai sinonim dengan rate of retum, earning power, dan profitability. Yang dimaksud rentabilitas yaitu kemampuan perusahaan untuk memperoleh laba. Kalau laba atau profit adalah jumlahnya, maka rentabilitas adalah kemampuan untuk memperoleh jumlah tersebut. Sedangkan bagi sector perbankan, rentabilitas adalah kemampuan bank dalam menghasilkan profit (laba) dari operasi bank (Abdullah,2003).

$$
\text { Rasio rentabilitas mampu }
$$
mengukur keberhasilan menajemen sebagaimana ditunjukkan oleh laba yang dihasilkan dari penjualan. 
Pertumbuhan rentabilitas ini besaran perbandingan antara beban ditandai dengan perubahan profit atau biaya operasional terhadap margin on sales. Dengan tingkat pendapatan operasional suatu profitabilitas yang tinggi berarti perusahaan pada periode tertentu perusahaan akan beroperasi pada (Riyadi,2004). Operational efficiency tingkat biaya rendah yang akhirnya ratio telah menjadi salah satu rasio akan menghasilkan laba yang tinggi (Ningsih,2008).

Salah satu bagian dari analisis rasio keuangan, analisis rasio rentabilitas (profitabilitas) juga didasarkan pada data keuangan histroris yang tujuan utamanya adalah memberi suatu indikasi kinerja perusahaan di masa yang akan datang. Informasi hasil kinerja perusahaan diperlukan agar investor sebagai pihak yang berkepentingan serta masyarakat umum dapat mengetahui tingkat kesehatan suatu perusahaan.

\section{Operational Efficiency}

\section{Ratio(OER)}

Operational efficiency ratio atau, dalam bahasa Indonesia, lebih dikenal sebagai rasio $\mathrm{BOPO}$ merupakan rasio yang menunjukkan yang perubahan nilainya sangat diperhatikan terutama bagi sector perbankan mengingat salah satu kriteria penentuan tingkat kesehatan bank oleh Bank Indonesia adalah besaran rasio ini.

Bank yang nilai Rasio BOPO tinggi menunjukkan bahwa bank tersebut tidak beroperasi dengan efisien karena tingginya nilai dari rasio ini memperlihatkan besarnya jumlah biaya operasional yang harus dikeluarkan oleh pihak bank untuk memperoleh pendapatan operasional. Di samping itu, jumlah biaya operasional yang besar akan memperkecil jumlah laba yang akan diperoleh karena biaya atau beban operasional bertindak sebagai faktor pengurang dalam laporan laba rugi. Nilai rasio BOPO yang ideal berada 
antara 50-75\% sesuai dengan peringkat yang akan diperoleh bank ketentuan Bank Indonesia. dari besaran nilai operational Berdasarkan Surat Edaran efficiency ratio yang dimiliki adalah Bank Indonesia No.6/23/DPNP sebagai berikut: tanggal 31 Mei 2004, kategori

Tabel1

\section{Peringkat bank berdasarkan operational efficiency ratio (BOPO)}

\begin{tabular}{|c|l|l|}
\hline Peringka & \multicolumn{1}{|c|}{ Predikat } & \multicolumn{1}{c|}{ Besaran nilai OER/BOPO } \\
\hline 1 & Sangat Sehat & $50-75 \%$ \\
\hline 2 & Sehat & $76-93 \%$ \\
\hline 3 & Cukup Sehat & $94-96 \%$ \\
\hline 4 & Kurang Sehat & $96-100 \%$ \\
\hline 5 & Tidak Sehat & $>100 \%$ \\
\hline
\end{tabular}

Sumber : SEBINo.6/23/DPNP tanggal 31 Mei 2004.

\section{Cost Efficiency Ratio(CER)}

Cost efficiency ratio merupakan rasio yang digunakan untuk mengukur seberapa besar biaya non-bunga yang dikeluarkan suatu bank demi menghasilkan pendapatan bunga bersih dan pendapatan lainnya selain pendapatan bunga (Timothy\&Scott, 2000).

Biaya non bunga atau noninterest expense yang biasa disebut sebagai overhead cost terdiri dari penyisihan kerugian atas aktiva produktif dan non-produktif, biaya tenaga kerja, tunjangan karyawan serta biaya administrasi \& umum (biaya listrik, telepon, sewa gedung, kendaraan, pemeliiharaan $\mathrm{dsb})$, sedangkan pendapatan nonbunga terdiri dari pendapatan komisi dan provisi non- kredit; pendapatan transfer, penolakan cek dan intercity; keuntungan transaksi valuta asing dan pendapatan jasa bank lainnya di luar pendapatan yang berhubungan dengan pemberian kredit. Pendapatan non bunga sering disebut sebagai feebased income. 
Alasan suatu bank kemampuan bank yang menggunakan rasio CER sebagai bersangkutan dalam menghasilkan indikator efisiensi karena biaya yang laba bersih (net income) ditinjau dari digunakan dalam menghitung CER sudut total penjualannya. NPM sebagian besar terdiri dari biaya mengacu kepada pendapatan variabel (variable cost) yang tak lain merupakan jenis biaya yang dapat ditekan, seperti biaya umum, administrasi dan tenaga kerja. Dan jika suatu bank mampu memperoleh pendapatan dalam jumlah besar dengan biaya yang relatif kecil, maka dapat dikatakan bahwa bank operasional bank yang terutama berasal dari kegiatan pemberian kredit yang dalam prakteknya memiliki berbagai risiko kredit (kredit bermasalah dan kredit macet), bunga (spread), kurs valas (jika kredit diberikan dalam valas).

Semakin tinggi tingkat rasio tersebut mampu untuk net profit margin bank yang mengoptimalkan segala sumber bersangkutan menunjukkan hasil daya yang dimilikinya (Riyadi,2004). yang semakin baik, demikian Besaran nilai rasio ini menurut sebaliknya (Muljono, 1999). Selain Timothy \&Scott (2000) untuk itu, rasio NPM juga memiliki predikat sangat baik adalah 50-55\% hubungan positif dengan laba dan semakin besar nilainya, semakin bersih, dimana semakin meningkat tidak efisien.

nilai rasio ini, semakin baik

\section{Net Profit Margin (NPM)}

NPM menunjukkan perbandingan antara laba bersih dengan penjualan (Hanafi dan Halim,2005). Rasio ini digunakan peningkatan perolehan laba bersih suatu bank, demikian juga sebaliknya.

\section{Hubungan antara Operational Efficiency Ratio (OER) \& Cost} untuk menghitung sejauh mana 


\section{Efficiency Ratio (CER) dengan}

Net Profit Margin (NPM)

Baik variabel dependen (NPM) maupun variable independen (OER\&CER) dalam penelitian ini merupakan bagian dari laporan laba-rugi. NPM dihitung berdasarkan hasil bagi antara laba bersih dan total penjualan, artinya semakin besar laba suatu bank, semakin tinggi nilai NPM bank tersebut. Di lain pihak, OER \& CER merupakan variable yang mencerminkan seberapa besar biayabiaya yang dikeluarkan oleh pihak bank dalam melaksanakan kegiatan operasional.

Jika OER menunjukkan seberapa efektif pihak bank dalam menekan seluruh biaya operasional, maka CER menunjukkan seberapa efektif pihak bank dalam menekan biaya overhead. Bedanya, nilai OER telah memasukkan biaya bunga dalam perhitungan sedangkan CER tidak memasukkan biaya bunga dalam perhitungan. Dengan kata lain, OER bertujuan untuk

memperlihatkan sejauh mana pihak bank mampu menekan biaya yang berkaitan dengan fungsi utama bank, yakni seluruh biaya yang timbul akibat dari kegiatan menghimpun dan menyalurkan dana, sedangkan CER hanya menunjukkan biaya yang timbul akibat dari penggunaan sumber daya dan alat pendukung bagi kegiatan operasional.

Menyangkut masalah biaya, OER dan CER memiliki pengaruh negative terhadap NPM karena dalam laporan laba rugi, biaya merupakan faktor pengurang. Oleh karena itu, semakin tinggi biayabiaya operasional bank, semakin besar factor pengurang dalam laporan laba rugi. Hal ini akan mengurangi jumlah laba bersih yang selanjutnya berakibat terhadap perolehan NPM. Dengan kata lain, semakin besar OER \& CER, semakin rendah NPM yang akan diperoleh.

\section{Hipotesis}


Hipotesis dapat diartikan laporan keuangan Bank Mandiri. sebagai suatu jawaban yang bersifat Sedangkan Sumber data yang sementara terhadap permasalahan digunakan dalam penelitian ini penelitian, sampai terbukti melalui data yang terkumpul (Santoso, 2010). Berdasarkan tinjauan pustaka dan kerangka di atas, maka hipotesis adalah (a)Diduga OER\&CER secara simultan berpengaruh signifikan terhadap NPM (b)Diduga OER \& CER secara parsial berpengaruh negative dan signifikan terhadap NPM.

\section{METODOLOGI PENELITIAN}

\section{Metodedan Sumber Data}

\section{Penelitian}

Penelitian ini berbentuk penelitian deskriptif kuantitatif yaitu penelitian yang mengungkap besar atau kecilnya suatu pengaruh atau hubungan antar variable yang dinyatakan dalam angka-angka.

Jenis data yang digunakan dalam penelitian ini adalah data sekunder, yakni data yang telah disediakan dan telah dipublikasikan oleh beberapa instansi terkait. Data semuanya berasal dari laporan keuangan baik yang dipublikasikan oleh Bank Rakyat Indonesia (BRI) maupun yang dipublikasikan lewat Bursa Efek Indonesia.

\section{Teknik Pengumpulan Data}

Teknik pengumpulan data yang digunakan dalam penelitian ini adalah metode pengumpulan data historis(documentary-historical). Langkah yang diambil dalam pengumpulan data yang berkaitan penelitian ini adalah penelitian kepustakaan yaitu untuk memperoleh data sekunder dan untuk mengetahui indikatorindikator dari variabel yang diukur.

\section{Variabel Penelitian}

\section{a. Variabel Penelitian}

Variabel terikat dalam penelitian ini adalah ne tprofit margin (NPM) yang diberi simbo $1 Y$, dengan indicator net income dan net sales. 


\section{b. Definisi Operasional}

Berdasarkan variable variabel penelitian seperti yang terlihat pada table di bawah ini.

penelitian di atas, penulis dapat

memaparkan operasionalisasi

Tabel 2

Operasionalisasi Variabel Penelitian

\begin{tabular}{|c|c|c|c|c|c|}
\hline No & NamaVariabel & StatusVariabel & Konsep & $\begin{array}{c}\text { Cara } \\
\text { Pengukuran }\end{array}$ & Skala \\
\hline 1. & $\begin{array}{l}\text { Operational } \\
\text { Efficiency Ratio } \\
\text { (OER) }\end{array}$ & Independen & $\begin{array}{l}\text { Menunjukkan seberapa } \\
\text { Efektif suatu bank dalam } \\
\text { menekan seluruh biaya } \\
\text { selama menjalankan } \\
\text { kegiatan operasional. } \\
\text { Riyadi(2004) }\end{array}$ & $\begin{array}{c}\text { Total Operatiing } \\
\text { Expenses } / \text { Total } \\
\text { Operating } \\
\text { Revenue }\end{array}$ & $\begin{array}{c}\text { Rasio } \\
(\%)\end{array}$ \\
\hline 2. & $\begin{array}{l}\text { Cost Efficiency } \\
\text { Ratio(CER) }\end{array}$ & Independen & $\begin{array}{l}\text { Menunjukkan seberapa } \\
\text { Efisien bank dalam } \\
\text { mengelola biaya overhead } \\
\text { untuk memperoleh } \\
\text { pendapatan bunga bersih } \\
\text { dan pend. Non bunga. } \\
\text { Riyadi(2004) }\end{array}$ & $\begin{array}{l}\text { Overheadcost/ } \\
\text { Net Interest } \\
\text { Income }+ \text { Fee } \\
\text { Based Income }\end{array}$ & $\begin{array}{c}\text { Rasio } \\
(\%)\end{array}$ \\
\hline 3. & $\begin{array}{l}\text { Net Profit } \\
\text { Margin(NPM) }\end{array}$ & Dependen & $\begin{array}{l}\text { Menunjukkan seberapa } \\
\text { Optimum suatu bank } \\
\text { dalam memeperoleh laba } \\
\text { bersih dari kegiatan } \\
\text { operasional utama } \\
\text { (penyaluran kredit). } \\
\text { Hanafi \& Halim (2005) }\end{array}$ & $\begin{array}{l}\text { Net Income/Net } \\
\text { Sales }\end{array}$ & $\begin{array}{c}\text { Rasio } \\
(\%)\end{array}$ \\
\hline
\end{tabular}

\section{Teknik Analisis Data}

Penelitian ini bertujuan

melihat pengaruh hubungan antara variabel-variabel independen terhadap variabel dependen dengan menggunakan analisis regresilinear berganda. Statistik untuk menguji hipotesis dalam penelitian ini menggunakan metode regresilinier berganda dengan rumus:

$$
\mathrm{Y}=\mathrm{a}+\mathrm{b} 1, \mathrm{~b} 2 \times 1 \times 2 \mathrm{Xi}
$$

Dimana :
$\mathrm{Y}=$
Net Profit Margin (dalam persentase)
$\mathrm{a}=$ Konstanta persamaan regresi
b1,b2, = Koefisien regresi
$\mathrm{x} 1=$ Operational efficiency Ratio (dalam persentase)
$\mathrm{x} 2=$ Cost Efficiency Ratio (dalam persentase) 
$\mathrm{e}=$ Standar error

\section{Pengujian Hipotesis}

\section{a. Uji Korelasi Parsial}

Uji korelasi merupakan

menafsirkan angka korelasi antar sebuah analisis yang digunakan variabel menurut Pratisto(2009) untuk menyelidiki hubungan digunakan kriteria sebagai berikut: antara dua variabel. Untuk

$\begin{array}{llll}0-0.25 & \text { atau } 0-25 \% & : & \text { korelasi } \\ >0,25-0,5 & \text { atau } 25-50 \% & : & \text { Korelasi cukup } \\ >0,5-0,75 & \text { atau } 50-75 \% & : & \text { Korelasi kuat } \\ >0,75-1 & \text { atau } 75-100 \% & : & \text { korelasi }\end{array}$

Probabilitas untuk Uji Korelasi ini adalah 0,025.

\section{b. Uji Koefesien Determinasi $\left(\mathbf{R}^{2}\right)$}

Koefisien determinasi $\left(\mathrm{R}^{2}\right)$ digunakan untuk mengukur seberapa jauh kemampuan model dalam menerangkan variasi TSS

$$
\begin{aligned}
& \mathrm{R}^{2}= \\
& \mathrm{ESS}
\end{aligned}
$$

$\mathrm{R}^{2}=$ Koefisien determinasi majemuk (multiple coefficient of determinant), yaitu proporsi variable terikat yang dapat dijelaskan oleh variable bebas secara bersama-sama.

ESS = Explainedsum of squares, atau jumlah kuadrat yang dijelaskan atau variabel nilai variable terikat yang ditaksirdi sekitar rata-ratanya.

TSS = Total sum of squares, atau total variable nilai variable terikat sebenarnya di sekitar rata-rata sampelnya.

Nilai koefisien determinasi kecil (mendekati nol) menunjukkan berada antara $0-1$. Nilai $\mathrm{R}^{2}$ yang kurangnya kemampuan variabel- 
variabel bebas dalam menjelaskan variasi pada variable terikat. Namun, nilai $\mathrm{R}^{2}$ yang mendekati 1 menunjukkan bahwa variabel-

\section{c. Uji Simultan (Uji F)}

Uji F digunakan untuk melihat signifikansi pengaruh perubahan variabel bebas (Operational Efficiency Ratio \& Cost Eefficiency Ratio) secara bersamasama atau simultan terhadap variable terikat (Net Profit Margin). Langkah-langkah yang dilakukan adalah (Gujarati,1999) :

(1)Merumuskan hipotesis $\mathrm{H} 0: \mathrm{b}_{1}=\mathrm{b}_{2}=0$, tidak ada pengaruh perubahan proporsi Operational Efficiency Ratio dan Cost Efficiency Ratio terhadap Net Profit Margin.

\section{HASIL PENELITIAN}

\section{Hasil Uji Korelasi}

Untuk mengetahui hubungan antara operational efficiency ratio (rasio BOPO) dan cost efficiency ratio (CER) terhadap net profit margin (NPM) pada Bank Mandiri digunakan pengujian korelasi. Uji korelasi variabel bebas memiliki hampir semua informasi yang dibutuhkan untuk memprediksi variasi pada variable terikat (Ghozali,2005).

$\mathrm{H} 1: \mathrm{b}_{1} \geq \mathrm{b}_{2} \geq 0$, terdapat pengaruh perubahan proporsi Operational efficiency Ratio dan Cost Efficiency Ratio terhadap Net Profit Margin (2)Menentukan tingkat signifikasi $(\alpha)$, yaitu sebesar $0,05 \quad(5 \%)$ dan degree of freedom (df) dengan rumus $\mathrm{n}-\mathrm{k}-1$ dengan tujuan untuk menentukan Ftabel

Membandingkan hasil Fhitung dengan Ftable dengan kriteria sebagai berikut : Jika Fhitung $>$ Ftabel berarti $\mathrm{H}_{1}$ diterima. Jika Fhitung $\leq$ Ftabel berarti $\mathrm{H} 0$ ditolak.

merupakan sebuah analisis yang digunakan untuk menyelidiki hubungan antar dua variabel. Hasil uji korelasi dapat dilihat pada table berikut ini: 
Tabel 3

Hasil Uji Korelasi

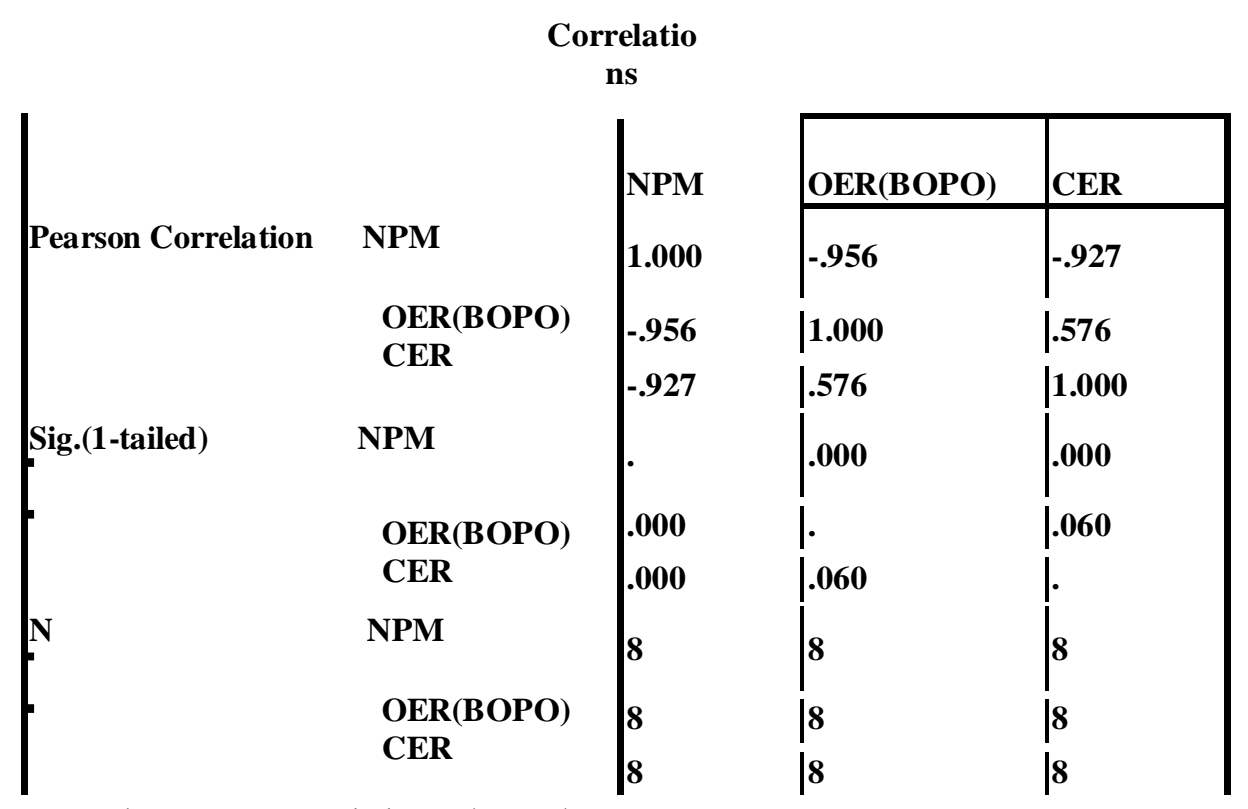

Sumber : Data Olahan (2017)

Untuk menafsirkan angka Pratisto (2009) digunakan kriteria

korelasi antar variabel menurut sebagai berikut:

0- $25 \%$ : korelasi sangat lemah (dianggap tidak ada)

26-50\% : korelasi cukup

$51-75 \% \quad$ : korelasi kuat

76-100\% : : korelasi sangat kuat

Berdasarkan data yang signifikan karena memiliki nilai diperoleh dari SPSS 25dapat probabilitas sebesar $0,000 \quad(<0,025)$ ditafsirkan hubungan antara (b) Terdapat korelasi negatif yang variabel-variabel adalah sebagai sangat kuat antara cost efficiency ratio berikut (a) Terdapat korelasi negatif (CER) dengan net profit margin yang sangat kuat antara operational (NPM) dengan nilai 92,7\%. Korelasi efficiency ratio (Rasio BOPO) dengan dua variabel tersebut signifikan net profit margin (NPM) dengan nilai karena memiliki nilai probabilitas 95,6\% Korelasi dua variable tersebut sebesar $0,000(<0,025)$.

2. Hasil Uji Koefisien Determinasi $\left(\mathbf{R}^{2}\right)$ 
Koefisien determinasi $\left(\mathrm{R}^{2}\right)$ variable terikat sangat lemah, digunakan untuk mengukur sedangkan nilai $R$ square yang seberapa jauh kemampuan model dalam menerangkan variasi pada variable terikat. Nilai $R$ square terletak antara nol dan satu. Jika nilai R square mendekati nol, maka kemampuan variable bebas dalam menjelaskan perubahan pada mendekati satu menunjukkan kuatnya pengaruh variabel bebas dalam menentukan segala perubahan yang terjadi pada variabel terikat (Santoso, 2010). Hasil uji koefisien determinasi ( $R$ square) table berikut:

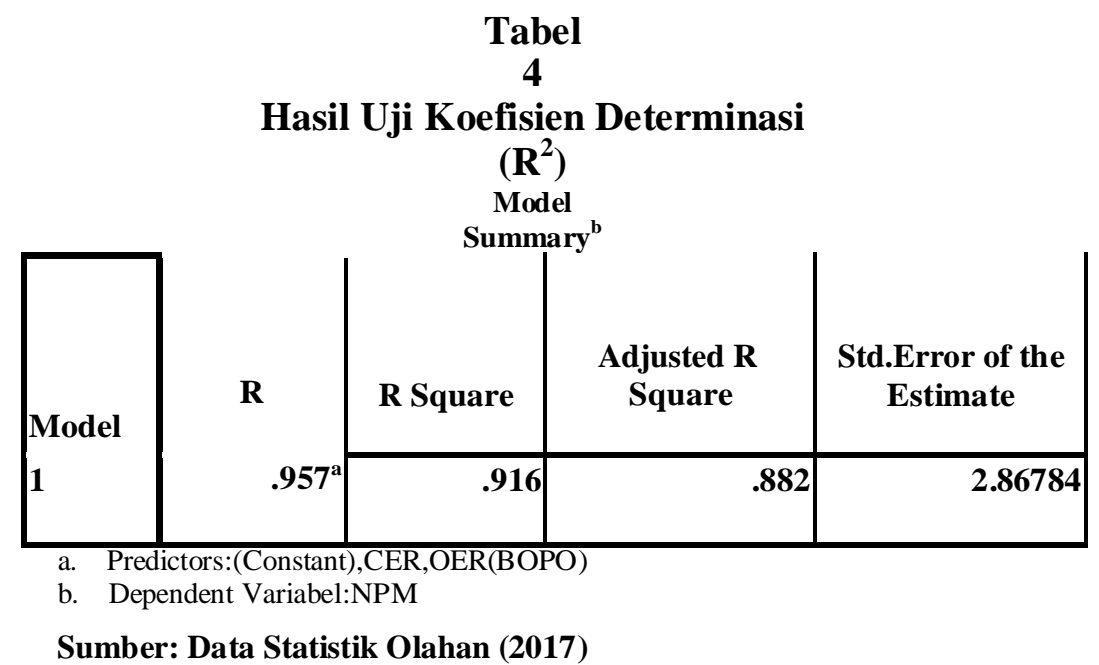

Tabel 4 menunjukkan bahwa 91,6\% atas setiap perubahan yang nilai Koefisien Determinasi $\left(\mathrm{R}^{2}\right)$ terjadi pada variable terikat, yakni dalam penelitian ini adalah 0,916 (mendekati satu). Artinya, operational efficiency ratio (rasio BOPO) dan cost efficiency ratio (CER) sebagai variable net profit margin (NPM), sedangkan sisanya sebesar $8,4 \%$ disebabkan oleh hal-hal lain di luar variable penelitian.

bebas memiliki pengaruh sebesar

\section{Hasil Pengujian Hipotesis}

a. Hasil Uji Simultan (Uji F) 
Uji F dilakukan untuk melihat pengaruh dari variable bebas secara bersama-sama (simultan) terhadap variabel terikat. Dalam halini, pengaruh antara operational efficiency ratio (rasio $\mathrm{BOPO}$ ) dan cost efficiency ratio (CER) secara simultan terhadap net profit margin (NPM). Hasil uji simultan (Uji F) tabel berikut:

\section{Tabel5}

\section{Hasil Uji F}

ANOVA $^{b}$

\begin{tabular}{|ll|r|}
\hline Model & & Sum of Squares \\
1 & Regression & 446.999 \\
& Residual & 41.123 \\
& Total & 488.121 \\
& &
\end{tabular}

a. Predictors:(Constant),CER,OER(BOPO)

b. Dependent Variable:NPM

Sumber: Data Statistik Olahan (2017)

Hasil olah data SPSS pada table 5 menunjukan nilai $\mathrm{F}$ hitung $=$ 27,175, sehingga diperoleh hasil Fhitung 27,175 $>$ Ftabel 4,07. Dan dengan tingkat signifikansi $(\alpha)$ sebesar 0,002 (di bawah 0,05), dapat disimpulkan bahwa operational efficiency ratio (rasio BOPO) dan cost effciciency ratio (CER) secara bersama-sama / serentak perpengaruh signifikan terhadap net Df
2
5
7

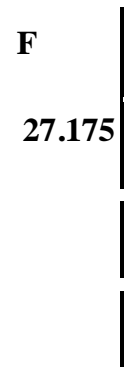

Sig. $.002^{\mathrm{a}}$ 8.225

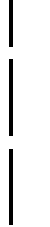

digunakan dalam model regresi untuk memprediksi NPM. Maka dari itu, H1 diterima dan H0 ditolak. Dengan demikian, hipotesis yang diajukan diterima berdasarkan hasil uji F ini.

\section{b. Uji Parsial (Uji t)}

Hubungan secara parsial ini dapat ditinjau dari nilai signifikansi, nilai thitung dan persamaan regresi linear berganda. profit margin (NPM) dan layak 


\begin{tabular}{|l|r|r|r|r|r|}
\multicolumn{7}{|c|}{$\begin{array}{c}\text { Coeffecient } \\
\text { a }\end{array}$} \\
\hline \multirow{3}{*}{ Model } & \multicolumn{1}{|c|}{ Unstandardized Coefficient } & $\begin{array}{c}\text { Standardized } \\
\text { Coefficienct }\end{array}$ & \multirow{2}{*}{ T } & \multirow{2}{*}{ Sig. } \\
\cline { 2 - 4 } & \multicolumn{1}{|c|}{ B } & \multicolumn{1}{|c|}{ Std.Error } & \multicolumn{1}{c|}{ Beta } & & $\mathbf{4 . 4 6 0}$ \\
\hline 1. Constant & 128.449 & $\mathbf{2 8 . 8 0 3}$ & & $\mathbf{. 0 0 7}$ \\
OER(BOPO) & -1.398 & .759 & -1.088 & -1.842 & .125 \\
CER & .116 & .507 & .135 & .228 & .828 \\
\hline
\end{tabular}

a. Dependent Variabel:NPM

Sumber: Data Sekunder Olahan(2017)

Dari hasil uji t (parsial) seperti yang ditunjukkan pada tabel 7dapat disusun persamaan regresilinear berganda seperti berikut ini :

\section{$\mathrm{NPM}=128,449-1,398 \mathrm{OER}(\mathrm{BOPO})+0,116 \mathrm{CER}$}

Berdasarkan table 7 dan persamaan regresi di atas dapat dinterpretasikan beberapa sebagai berikut (1) Operational efficiency ratio (Rasio BOPO) memiliki nilai signifikansi sebesar $0,125 \quad(>0,05)$ dengan nilai thitung $\quad(-1.842)<$ ttabel $(2,015)$. Oleh karena itu, operational efficiency ratio (rasio BOPO), sebagai variable $\mathrm{X}_{1}$ dalam penelitian ini, secara parsial tidak memiliki pengaruh yang signifikan terhadap net profit margin (NPM). Nilai B yang sebesar -1,398 menunjukkan bahwa setiap terjadi kenaikan pada rasio BOPO sebesar 1\%, maka nilai NPM akan berkurang sebesar1,398\%. (2)Cost efficiency ratio (CER) memiliki nilai signifikasi sebesar
$0,828(>0,05)$ dengan nilai thitung 0,228 < ttabel 2,015. Oleh karena itu, CER sebagai variable $\mathrm{X}_{2}$ dalam penelitian ini, secara parsial tidak memiliki pengaruh yang signifikan terhadap net profit margin (NPM). Nilai B yang sebesar 0,116 menunjukkan bahwa setiap terjadi kenaikan pada CER sebesar 1\%, maka nilai NPM justru bertambah sebesar $0,116 \%$. Hal tersebut sejalan dengan hasil penelitian Hays dkk (2010) dimana cost efficiency ratio memiliki pengaruh positif terhadap net profit margin (3) Net profit margin (NPM), sebagai variable terikat, akan memiliki nilai tetap sebesar $128,449 \%$ seandainya operational 
efficiency ratio (rasio BOPO) dan disebabkan oleh tingkat signifikansi costefficiency ratio (CER) tidak ada. kedua variable bebas yang masih

Dari hasil uji parsial di atas sebenarnya telah didapatkan variabel bebas mana yang memiliki dominasi yang kuat. Hal tersebut didasarkan atas seberapa besar perubahan pada variable terikat yang disebabkan oleh variabelvariabel bebas. Dan dari hasil uji parsial pada penelitian ini diketahui bahwa variable $\mathrm{X}_{1},(\mathrm{OER} / \mathrm{BOPO})$ mampu mengubah variabel bebas, NPM sebesar 1,398\% sedangkan variabel $\mathrm{X}_{2}, \mathrm{CER}$ hanya mampu mengubah NPM sebesar 0,116\%. Dengan demikian, variable $\mathrm{X}_{1}$ atau operational efficiency ratio (rasio BOPO) adalah variabel bebas yang memiliki pengaruh paling dominan dalam menentukan NPM.

Hasil uji parsial di atas belum menunjukkan ketepatan yang akurat dalam menentukan variable bebas mana yang dominan, hal tersebut berada di atas 0,05 (5\%). Belum signifikannya hasil uji $\mathrm{t}$ (parsial) penelitian ini dapat disebabkan oleh perubahan angka yangekstrim, seperti yang terjadi pada tahun 2009, dan perubahan nilai variabel bebas yang serupa. Maka dari itu, untuk membuktikan variabel bebas mana yang paling mendominasi dengan tingkat ketepatan yang akurat, penulis mengadakan pengujian parsial dengan metode stepwise, yakni dengan cara mencari variable bebas yang memiliki dominasi yang kuat dan mengeluarkan variabel bebas yang memiliki dominasi yang lemah secara parsial.

\section{Dari motode stepwise} diperoleh hasil uji t sebagai berikut :

Tabel 8

Hasil Uji t (Metode

Stepwise) 


\begin{tabular}{|c|c|c|c|c|c|}
\hline \multicolumn{6}{|c|}{$\underset{\mathbf{a}}{\text { Coeffecient }}$} \\
\hline \multirow{2}{*}{ Model } & \multicolumn{2}{|c|}{ Unstandardized Coefficient } & Standardized & \multirow{2}{*}{$\mathbf{T}$} & \multirow{2}{*}{ Sig. } \\
\hline & B & Std.Error & Beta & & \\
\hline $\begin{array}{ll}\text { 1. } & \text { Constant } \\
\text { OER(BOPO) }\end{array}$ & $\begin{array}{r}122.871 \\
-1.229\end{array}$ & $\begin{array}{r}14.000 \\
.153\end{array}$ & -.956 & $\begin{array}{r}8.771 \\
-8.030\end{array}$ & $\begin{array}{l}.000 \\
.000\end{array}$ \\
\hline
\end{tabular}

a. Dependent Variabel:NPM

Sumber: Data Sekunder Olahan(2017)

Dari hasil uji $\mathrm{t}$ dalam metode stepwise. operational efficiency ratio sebagai variabel bebas yang paling berpengaruh dan dominan terhadap NPM sebagai variable terikat. Nilai signifikansi sebesar 0,000 $(<0,05)$.

\section{KESIMPULAN}

a. Operational efficiency ratio (Rasio BOPO) dan cost efficiency ratio (CER) memiliki pengaruh sebesar $91,6 \%$ dalam menjelaskan setiap perubahan nilai net profit margin (NPM) antara tahun 2008 dan 2016, sedangkan sisanya sebesar $8,4 \%$ dijelaskan oleh variabelvariable lain di luar model penelitian.

b. Secara simultan, operational efficiency ratio (rasio BOPO) dan cost efficiency ratio (CER) berpengaruh signifikan terhadap net profit margin (NPM) sesuai dengan hasil temuan pada Uji F.
Hasil Uji simultan ini dapat memperkuat alasan bahwa penurunan nilai NPM secara ekstrim pada tahun 2009 di Bank Rakyat Indonesia (BRI) disebabkan oleh membengkaknya nilai OER (rasio BOPO) dan CER secara serentak pada tahun yang sama.

c. Secara parsial, operational efficiency ratio (rasio $\mathrm{BOPO}$ ) berpengaruh negatif, namun cost efficiency ratio (CER) ternyata memiliki pengaruh posistif. Bank Rakyat Indonesia (BRI), perkembangan total biaya non bunga, yang menjadi indicator CER, ternyata dapat mendongkrak total penjualan yang menjadi indicator NPM, khususnya pada tahun 2011, dimana terjadi peningkatan total penjualan disaat bank itu sedang merugi. Dan di antara dua variabel bebas tersebut, variabel 
$\mathrm{X} 1$, operational efficiency ratio

(rasio BOPO) yang berpengaruh dominan secara parsial terhadap

\section{DAFTAR PUSTAKA}

Arbi, M. Syarif.2013. Mengenal Bankdan Lembaga Keuangan Non-Bank. Djambatan. Jakarta Abdullah, Faisal. 2013. Manajemen Perbankan (Teknik Analisis Kinerja Keuangan Bank). UMM. Malang

Bank Indonesia. 2016. Laporan Perekonomian Indonesia

http://www.docstoc.com/docs/BankPerformance-Measures diakses 13 Pebruari 2017

http://www.ibsintelligence.com diakses 13 Pebruari 2017

Ikatan Akuntan Indonesia. 2014. Standar Akuntansi Keuangan. Penerbit Salemba Empat. Jakarta.

Kohn, Meir. 1993. Money, Banking E Financial Markets. Elm Street Publishing Services, Inc. $2^{\text {nd }}$ edition. Florida.

Koch, Timothy W., dan S. Scott Mac Donald. 2011. Bank variable terikat, yakni net profit margin (NPM).

Management. Hartcourt College Publishers. $4^{\text {th }}$ edition. Orlando.

Laporan Tahunan Bank Indonesia. 2011 $\&$ 2016(http://www.bi.go.id/di akses 11 Pebruari 2017 Muljono, TeguhPudjo. 1999. Analisa Laporan Keuangan untuk Perbankan. Penerbit Djambatan. Jakarta

Saunders, Anthony. 2000. Financial Institution Management: A Modern Perspective. The Mc Graw-Hill Companies, Inc. $3^{\text {rd }}$ edition. USA.

Santoso, Singgit. 2014. Mastering SPSS25. Penerbit PT Elex Media Komputindo. Jakarta. Shao, Stephen Pinyee. 1990. Mathematic forManagement and Finance. SouthWestwern Publishing Co. $6^{\text {th }}$ edition.

Ohio. 